\title{
Physio-biochemical Changes in Sorghum Cultivars under Different Moisture Regimes
}

\author{
Sujata Pawar B. ${ }^{*}$ and Gagakh S. R.
}

Dept. of Agriculture Botany, Mahatma Phule Krishi Vidyapeeth, Rahuri, District Ahmednagar, Maharashtra (413 722), India

\section{Article History}

Manuscript No. AR1267

Received in $2^{\text {nd }}$ February, 2015

Received in revised form $25^{\text {th }}$ January, 2016

Accepted in final form $1^{\text {st }}$ February, 2016

\section{Correspondence to}

*E-mail: papupawar65@gmail.com

\section{Keywords}

Sorghum, moisture regimes, physio-

biochemical and yield parameters

\begin{abstract}
An experiment was conducted to evaluate the effects of water deficit on physiobiochemical and yield parameters on sorghum during rabi season (September 2009 to February 2010) in Maharashtra. The treatment combinations consisted of four moisture regimes viz., $\mathrm{M}_{1}, \mathrm{M}_{2}, \mathrm{M}_{3}$ and $\mathrm{M}_{4}$ upto harvest and six genotypes viz., Phule Yashoda, RSV-1006, Phule Chitra, Phule Vasuda, Phule Anuradha, Phule Maulee. The study revealed that, Phule Yashoda and Phule Revati genotypes had maximum mean growth parameters and hence had maximum yield and yield contributing characters at lower moisture regime $\mathrm{M}_{1}$ than non-stress condition $\mathrm{M}_{4}$. RSV-1006 and Phule Chitra genotypes had maximum total soluble sugar content. The proline content increased with a decrease in the soil moisture content in all the genotypes with predominance in Phule Maulee, Phule Chitra and Phule Anuradha which also reported positive correlation of proline accumulation with grain yield. The degree of reduction in protein content as a function of water stress was less in Phlule Maulee, Phule Chitra and Phule Anuradha respectively. The genotypes Phlule Maulee, Phule Chitra and Phule Anuradha had lowest nitrate reductase activity under moisture regime $\mathrm{M}_{1}$. Among the six genotypes, Phule Yashoda and Phule Revati showed higher grain yield and yield contributing parameters. The present study revealed that genotypes Phule Chitra and Phule Maulee are more suited under limited soil moisture condition. Irrespective of moisture regime Phule Yashoda and RSV-1006 found better than rest of genotypes. Therefore, these genotypes are well suited for medium soil under stress as well as non-stress conditions.
\end{abstract}

\section{Introduction}

Sorghum is grown mostly in drought prone areas, which fall under semiarid (basaltic) agro-climatic zone and characterized by scanty, erratic and ill distributed rainfall, varying from 500 to $700 \mathrm{~mm}$. The variation in the duration and amount of rainfall creates a broad range of environment for the crop production. The rabi sorghum is the predominant crop of drought prone areas grown on the receding soil moisture. However, the sorghum production is very low and unstable due to water stress under prevailing rainfall situation. Moisture stress is the most important limiting factor in dry land agriculture for crop growth and ultimately reflects in low production. The growth period from 9 to 13 weeks is crucial in the life period of rabi sorghum, which is sensitive to availability of soil moisture. During this period if this crop suffers due to sever moisture stress, it will affect the level of grain production (Belum et al., 2010).

The main characteristic of the sorghum is drought resistance because of the ability to minimize tissue water loss (Rao and Sinha, 1990). Grain sorghum leaf tissue has high desiccation tolerance. Sorghum being a $\mathrm{C}_{4}$ plant has the capacity to use increasing light intensities prevailing during rabi season. Under stress, plants offer some adaptive mechanisms including accumulation of biochemical components acting as osmoregulators. These include the accumulation of proline, reducing sugars, free amino acids and proteins. Under these situations some enzymes are very active to counteract these stress environments (Maiti et al., 2000; Zala et al., 2014). During the onset of stress, within the plants all major processes such as protein synthesis, energy metabolism, lipid metabolism and the reductive metabolism are altered significantly (Flores and Galston, 1984). Several enzymes have been shown to be affected by water stress in different plants (Mali and Mehta, 1977) and the degree of stress tolerance has been positively correlated with the level of certain organic solutes like proline and glycine. Solutes like proline and glycine betaine 
in a number of crop plants (Barnett and Naylor, 1966). Accumulation of proline, is considered to be an important character responsible for drought tolerance (Blum and Ebercon, 1976). An increase of amino pool size induced by water stress has also been reported in various crop plants, probably suggesting modification in protein turn over.

For rabi sorghum, water stress is one of the major factors limiting the crop growth and ultimately the production under rainfed farming. Certain species of sorghum have a versatile characteristic of withstanding the drought condition and thus having a genetic potential to defend the stress condition. In the present investigation, some of the existing and recently released cultivars of sorghum are taken to test their water stress tolerance. These cultivars are presently used extensively in the commercial production in Indian farmers.

\section{Materials and Methods}

The present investigation was conducted from (September 2009 to February 2010) at Sorghum Improvement project, Mahatma Phule Krishi Vidyapeeth (MPKV) Rahuri, District Ahmednagar, Maharashtra, India. The seeds were obtained from Sorghum Improvement Project, MPKV, Rahuri. The Soil of experiment field was medium black type with bulk density of 1.3. The moisture content at field capacity and permanent wilting point were 34.40 and $21.66 \%$, respectively. The field experiment was laid out in a Factorial Randomized Blok Design (FRBD) with three replications in field condition. A field trials consisting of $\mathrm{M}_{1}$ ( $25 \%$ of field capacity), $\mathrm{M}_{2}$ ( $50 \%$ of field capacity), $M_{3}$ ( $75 \%$ of field capacity) and $M_{4}(>90 \%$ of field capacity) moisture regimes along with six genotypes $\mathrm{V}_{1}$ : Phule Yashoda, $\mathrm{V}_{2}$ : RSV-1006, $\mathrm{V}_{3}$ : Phule Chitra, $\mathrm{V}_{4}$ : Phule Vasuda, $\mathrm{V}_{5}:$ Phule Anuradha, $\mathrm{V}_{6}:$ Phule Maulee was under taken.

\subsection{Physiological characterization}

Plant height $(\mathrm{cm})$ of five randomly selected plants from each plot was recorded by measuring from the base of fully expanded leaf. After emergence of ear head, the height was measured up to the tip of ear head. Length $(\mathrm{cm})$ of fully expanded leaf of each selected tagged plants was measured from the tip of the leaves up to the leaf sheath. The total leaf area plant $t^{-1}\left(\mathrm{dm}^{2}\right)$ is measured by leaf area meter. Flag leaf area of each observational plant was measured in $\mathrm{dm}^{2}$ at the interval of 30 days starting from flag leaf initiation up to harvesting. The observational plants were cut close to the ground and flag leaf was separated from the stem. By taking the maximum length and width at the broadest point of all the flag leaves and multiplying by the factor 0.747 flag leaf area was calculated. Leaf area index (LAI) was calculated from the data of leaf area plant $^{-1}\left(\mathrm{dm}^{2}\right)$ according to the formula given by Watson (1947). Leaf area duration (LAD) was calculated by the formula given by Watson, (1947). The plants used for the estimation of leaf area were used for dry matter studies. Different components i.e. stem, leaves and ear head were separated and dried in the hot air oven initially at $90^{\circ} \mathrm{C}$ for one hour and subsequently at $60{ }^{\circ} \mathrm{C}$ till constant dry weight was obtained. Then dry weight was recorded repeatedly for each plant part. From this total dry matter plant ${ }^{-1}$ was computed. All the above observations were recorded at harvest stage.

\subsection{Biochemical characterization}

Various biochemical parameters were measured at 30 DAS, 60 DAS, 90 DAS and 120 DAS. The free proline level was determined at $520 \mathrm{~nm}$ (Bates et al., 1973), the total soluble carbohydrate level at $490 \mathrm{~nm}$ (Dubois et al., 1956), the soluble proteins at $750 \mathrm{~nm}$ (Lowery et al., 1951) and in vivo Nitrate reductase assay at $540 \mathrm{~nm}$ (Hageman and Hucklesby (1971); (Munjal et al., 1998).

\subsection{Post harvest studies (at harvest)}

In post harvest studies (at harvest) the length of the ear head, dry weight of ear head (g), 1000 grain weight (g), Grain yield $(\mathrm{kg})$ net $^{-1}$ plot, Grain yield (q ha $\left.{ }^{-1}\right)$, biological yield (q ha- ${ }^{-1}$, adding fodder yield and ear head weight) and harvest index (\%) were studied.

Fisher's method was used for data analysis and interpretation as suggested by Panse and Sukatme (1967). The level of significance used in ' $\mathrm{F}$ ' and ' $\mathrm{t}$ ' test was $p=0.05$. Critical difference $(\mathrm{CD})$ values were calculated at $5 \%$ probability level, wherever ' $F$ ' test was significant.

\section{Results and Discussion}

\subsection{Physiological characterization}

At harvest, the genotype $V_{1}$ (Phule Yashoda) showed significantly highest mean plant height $(256.73 \mathrm{~cm})$ while significantly lowest plant height $(208.00 \mathrm{~cm})$ was observed in $\mathrm{V}_{5}$ (Phule Anuradha). The genotypes $\mathrm{V}_{1}$ (Phule Yashoda) and $\mathrm{V}_{2}$ (RSV-1006) showed better growth under moisture regime $\mathrm{M}_{1}$ (at $25 \%$ of F.C.) seems to be drought tolerant (Table 1). This may be because of increased translocation of stored photosynthesis from the stem reserves when the current photosynthesis ceases due to water stress particularly during grain filling and grain development period (Kumar, 2009). In general, reduced plant height is an advantage under limited water condition by virtue of its reduction in leaf area and thus reducing the water being transpired. These results are in conformity with Chaudhari and Mahajan (1978), Hiremath and Parvatikar (1985); Gaosgelwe and Kirshan (1990); (Patil et al., 2003); Chand and Singh (2003).

The genotype $V_{1}$ (Phule Yashoda) was recorded significantly highest mean number of leaves plant ${ }^{-1}$ (3.95) and mean leaf area plant ${ }^{-1}(14.82)$, while significantly lowest was observed in $\mathrm{V}_{5}$ (Phule Anuradha). These results are in agreement 


\begin{tabular}{|c|c|c|c|c|c|c|c|c|c|c|c|c|c|c|c|}
\hline $\begin{array}{l}\text { Mois- } \\
\text { ture } \\
\text { regimes }\end{array}$ & $\begin{array}{l}\text { Mean } \\
\text { plant } \\
\text { height } \\
(\mathrm{cm})\end{array}$ & $\begin{array}{l}\text { Num- } \\
\text { ber of } \\
\text { leaves }\end{array}$ & $\begin{array}{c}\text { Leaf } \\
\text { area } \\
\left(\mathrm{dm}^{2}\right)\end{array}$ & LAI & $\begin{array}{l}\text { LAD } \\
\text { (days) }\end{array}$ & $\begin{array}{l}\text { Total } \\
\text { dry } \\
\text { matter } \\
\text { plant }^{-1} \\
(\mathrm{~g})\end{array}$ & $\begin{array}{c}\text { Length } \\
\text { of ear } \\
\text { head } \\
(\mathrm{cm})\end{array}$ & $\begin{array}{l}\text { Girth } \\
\text { of } \\
\text { ear } \\
\text { head } \\
\left(\mathrm{cm}^{2}\right)\end{array}$ & $\begin{array}{c}\text { Dry } \\
\text { weight } \\
\text { of ear } \\
\text { head } \\
\text { (g) }\end{array}$ & $\begin{array}{c}1000 \\
\text { grain } \\
\text { weight } \\
(\mathrm{g})\end{array}$ & $\begin{array}{l}\text { Grain } \\
\text { yield } \\
\text { plot }^{-1} \\
(\mathrm{~kg})\end{array}$ & $\begin{array}{l}\text { Fod- } \\
\text { der } \\
\text { yield } \\
\text { ha }^{-1}\end{array}$ & $\begin{array}{c}\text { Bio- } \\
\text { logical } \\
\text { yield } \\
(\mathrm{q} \\
\left.\mathrm{ha}^{-1}\right) \\
\end{array}$ & $\begin{array}{c}\text { Grain } \\
\text { yield } \\
\mathrm{ha}^{-1}\end{array}$ & $\begin{array}{l}\text { Har- } \\
\text { vest } \\
\text { index }\end{array}$ \\
\hline $\mathrm{M}_{1}$ & 223.63 & 2.59 & 10.96 & 1.62 & 65.46 & 169.40 & 19.49 & 6.12 & 72.53 & 37.00 & 1.90 & 65.86 & 90.96 & 24.98 & 27.38 \\
\hline $\mathrm{M}_{2}$ & 231.21 & 3.14 & 12.04 & 1.78 & 74.10 & 184.33 & 20.65 & 6.66 & 77.29 & 38.15 & 2.45 & 84.98 & 117.35 & 32.37 & 27.42 \\
\hline$M_{3}$ & 236.13 & 3.58 & 12.59 & 1.86 & 83.22 & 199.79 & 21.84 & 6.90 & 84.13 & 40.46 & 2.66 & 90.19 & 125.30 & 35.11 & 27.92 \\
\hline $\mathrm{M}_{4}$ & 245.52 & 3.96 & 13.39 & 1.98 & 87.17 & 221.55 & 23.11 & 7.07 & 89.53 & 41.44 & 2.81 & 95.58 & 132.72 & 37.14 & 27.91 \\
\hline $\operatorname{SEm} \pm$ & 0.135 & 0.135 & 0.201 & 0.029 & 0.657 & 0.378 & 0.124 & 0.235 & 0.151 & 0.176 & 0.010 & 0.250 & 0.333 & 0.140 & 0.102 \\
\hline $\begin{array}{l}\mathrm{CD} \\
(p=0.05)\end{array}$ & 0.374 & 0.374 & 0.559 & 0.082 & 1.822 & 1.050 & 0.345 & 0.656 & 0.418 & 0.488 & 0.029 & 0.694 & 0.923 & 0.390 & 0.283 \\
\hline \multicolumn{16}{|c|}{ Genotypes } \\
\hline $\mathrm{V}_{1}$ & 256.73 & 3.95 & 14.82 & 2.20 & 94.24 & 216.81 & 22.84 & 7.04 & 95.03 & 40.60 & 2.78 & 94.01 & 130.6 & 36.65 & 28.04 \\
\hline $\mathrm{V}_{2}$ & 256.63 & 3.66 & 13.11 & 1.94 & 83.90 & 216.36 & 22.51 & 7.40 & 83.62 & 40.94 & 2.77 & 92.69 & 129.4 & 36.61 & 28.25 \\
\hline $\mathrm{V}_{3}$ & 226.29 & 3.24 & 11.74 & 1.74 & 74.09 & 191.43 & 21.11 & 6.78 & 80.39 & 39.34 & 2.51 & 84.97 & 118.2 & 33.16 & 28.01 \\
\hline $\mathrm{V}_{4}$ & 237.97 & 3.45 & 12.37 & 1.83 & 77.73 & 199.47 & 22.72 & 7.15 & 88.56 & 40.66 & 2.75 & 92.66 & 129.0 & 36.28 & 28.09 \\
\hline $\mathrm{V}_{5}$ & 208.00 & 2.65 & 9.86 & 1.46 & 63.38 & 151.41 & 18.27 & 5.66 & 63.42 & 35.39 & 1.77 & 68.65 & 91.97 & 23.32 & 25.42 \\
\hline $\mathrm{V}_{6}$ & 219.48 & 2.95 & 11.56 & 1.71 & 71.59 & 187.13 & 20.19 & 6.09 & 74.18 & 38.64 & 2.15 & 71.94 & 100.4 & 28.41 & 28.14 \\
\hline $\operatorname{SEm} \pm$ & 0.165 & 0.165 & 0.247 & 0.036 & 0.805 & 0.464 & 0.152 & 0.288 & 0.184 & 0.215 & 0.013 & 0.306 & 0.408 & 0.172 & 0.125 \\
\hline $\begin{array}{l}\mathrm{CD} \\
(p=0.05)\end{array}$ & 0.459 & 0.459 & 0.684 & 0.101 & 2.231 & 1.286 & 0.423 & 0.797 & 0.512 & 0.598 & 0.036 & 0.850 & 1.131 & 0.478 & 0.397 \\
\hline \multicolumn{16}{|c|}{ Interaction } \\
\hline $\mathrm{SEm} \pm$ & 0.331 & 0.331 & 0.494 & 0.073 & 1.610 & 0.928 & 0.305 & NS & 0.369 & 0.431 & 0.026 & 0.613 & 0.816 & 0.345 & 0.250 \\
\hline $\begin{array}{l}\text { CD } \\
(p=0.05)\end{array}$ & 0.918 & N.S. & N.S. & N.S. & 4.463 & 2.572 & 0.847 & NS & 1.025 & 1.196 & 0.072 & 1.701 & 2.262 & 0.957 & 0.694 \\
\hline
\end{tabular}

with the finding of (Zhang et al., 2004), Abdalla and ElKhoshiban, (2007). Effects of water stress on growth/ morphological parameters such as leaf area, number of leaves and girth (diameter) have been documented by (Zhang et al., 2004); Abdalla and El-Khoshiban, (2007). These results are in conformity to the reduction in leaf area would limit the development of plant transpiration surface and keeps sink demand well balanced with plant assimilatory capacity (Bayoumi et al., 2008). Similarly, genotype $V_{1}$ (Phule Yashoda) recorded significantly highest mean leaf area index (2.20). Earlier studies also indicated similar observations with particular reference to sorghum grown under water stress condition (Kulkarni et al., 1981); Narkhede et al. (1998); Sonawane et al. (2008). Similarly, genotype $\mathrm{V}_{1}$ (Phule Yashoda) noticed significantly highest mean leaf area duration plant $^{-1}$ (94.24). In general water stress occurring during post flowering (i.e. early grain development) reduces final dry matter production Khannan et al. (1994). So, the production of maximum biomass under water deficit condition indicated that the dry matter production can be used as selection criterion for drought tolerance in sorghum than dry matter production under adequate water supply.

\subsection{Biochemical characterization}

The total sugar content, proline content, protein content and NR activity as influenced by different genotypes and moisture regimes and their interactions at critical growth stages of field condition are presented in Table 2. At 30 DAS, genotype $\mathrm{V}_{2}$ (RSV-1006) showed significantly highest total sugar (22.21 $\left.\mathrm{mg} \mathrm{g}^{-1} \mathrm{FW}\right)$, protein $\left(4.09 \mu\right.$ mole g $\left.{ }^{-1} \mathrm{FW}\right)$, NR activity $(3.11 \mu$ moles of $\mathrm{NO}_{2}^{-}$formed $\mathrm{g}^{-1} \mathrm{f}$. wt. $\mathrm{h}^{-1}$ ) while lowest proline content $\left(0.40 \mu\right.$ mole $\left.\mathrm{g}^{-1} \mathrm{FW}\right)$. The genotype $\mathrm{V}_{5}$ (Phule Anuradha) showed significantly lowest total sugar (17.68 $\left.\mathrm{mg} \mathrm{g}^{-1} \mathrm{FW}\right)$. The genotype $\mathrm{V}_{6}$ (Phule Maulee) recorded significantly highest proline content $\left(0.75 \mu\right.$ mole $\left.^{-1} \mathrm{FW}\right)$ and lowest protein content (3.31 $\mu$ mole $\left.\mathrm{g}^{-1} \mathrm{FW}\right)$. Similar trend was noticed at 60, 90 and at harvest as that of 30 DAS.

At 30 DAS, moisture regime $\mathrm{M}_{4}$ recorded significantly highest 


\begin{tabular}{|c|c|c|c|c|c|c|c|c|c|}
\hline $\begin{array}{l}\text { Moisture } \\
\text { regimes }\end{array}$ & $\begin{array}{l}\text { Total sug- } \\
\text { ar content } \\
\left(\mathrm{mg} \mathrm{g}^{-1}\right. \\
\text { FW) }\end{array}$ & $\begin{array}{c}\text { Proline } \\
\text { content of } \\
\text { leaves } \\
(\mu \text { mole } \\
\left.\mathrm{g}^{-1} \mathrm{FW}\right)\end{array}$ & $\begin{array}{c}\mathrm{PCL} \\
(\mu \\
\text { mole } \\
\mathrm{g}^{-1} \\
\mathrm{FW})\end{array}$ & $\begin{array}{l}\text { NRAL } \\
(\mu \text { moles } \\
\text { of } \mathrm{NO}_{2}^{-} \\
\text {form } \mathrm{g}^{-1} \mathrm{f} \text {. } \\
\left.\text { wt. } \mathrm{h}^{-1}\right)\end{array}$ & $\begin{array}{l}\text { Moisture } \\
\text { regimes }\end{array}$ & $\begin{array}{l}\text { Total sug- } \\
\text { ar content } \\
\left(\mathrm{mg} \mathrm{g}^{-1}\right. \\
\text { FW) }\end{array}$ & $\begin{array}{c}\text { Proline } \\
\text { content of } \\
\text { leaves } \\
(\mu \text { mole } \\
\left.\mathrm{g}^{-1} \mathrm{FW}\right)\end{array}$ & $\begin{array}{c}\mathrm{PCL} \\
(\mu \\
\text { mole } \\
\mathrm{g}^{-1} \\
\mathrm{FW})\end{array}$ & $\begin{array}{c}\text { NRAL } \\
(\mu \text { moles } \\
\text { of } \mathrm{NO}_{2}^{-} \\
\text {form } \mathrm{g}^{-1} \mathrm{f} \text {. } \\
\text { wt. } \mathrm{h}^{-1} \text { ) }\end{array}$ \\
\hline \multicolumn{5}{|l|}{ At $30 \mathrm{DAS}$} & \multicolumn{5}{|c|}{ Moisture regimes at $90 \mathrm{DAS}$} \\
\hline $\mathrm{M}_{1}$ & 18.41 & 0.63 & 3.41 & 2.38 & $\mathrm{M}_{1}$ & 21.99 & 1.33 & 2.99 & 2.21 \\
\hline $\mathrm{M}_{2}$ & 19.69 & 0.60 & 3.71 & 2.50 & $\mathrm{M}_{2}$ & 23.15 & 1.27 & 3.26 & 2.36 \\
\hline $\mathrm{M}_{3}$ & 20.74 & 0.58 & 4.17 & 2.61 & $\mathrm{M}_{3}$ & 23.91 & 1.20 & 3.50 & 2.46 \\
\hline $\mathrm{M}_{4}$ & 22.36 & 0.55 & 4.32 & 2.67 & $\mathrm{M}_{4}$ & 25.27 & 1.15 & 3.72 & 2.57 \\
\hline $\mathrm{SEm} \pm$ & 0.084 & 0.005 & 0.005 & 0.059 & $\mathrm{SEm} \pm$ & 0.030 & 0.005 & 0.005 & 0.050 \\
\hline $\mathrm{CD}(p=0.05)$ & 0.233 & 0.015 & 0.015 & 0.163 & $\mathrm{CD}(p=0.05)$ & 0.085 & 0.015 & 0.015 & 0.139 \\
\hline \multicolumn{5}{|l|}{ Genotypes } & \multicolumn{5}{|l|}{ Genotypes } \\
\hline $\mathrm{V}_{1}$ & 20.64 & 0.44 & 4.03 & 3.08 & $\mathrm{~V}_{1}$ & 23.99 & 1.14 & 3.09 & 2.69 \\
\hline $\mathrm{V}_{2}$ & 22.21 & 0.40 & 4.09 & 3.11 & $\mathrm{~V}_{2}$ & 26.01 & 0.86 & 3.91 & 2.89 \\
\hline $\mathrm{V}_{3}$ & 21.71 & 0.72 & 3.89 & 2.68 & $\mathrm{~V}_{3}$ & 25.13 & 1.43 & 3.43 & 2.49 \\
\hline $\mathrm{V}_{4}$ & 19.41 & 0.59 & 4 & 3.03 & $\mathrm{~V}_{4}$ & 22.48 & 1.16 & 3.79 & 2.88 \\
\hline $\mathrm{V}_{5}$ & 17.68 & 0.66 & 3.99 & 1.59 & $\mathrm{~V}_{5}$ & 20.9 & 1.21 & 3.3 & 1.85 \\
\hline $\mathrm{V}_{6}$ & 20.17 & 0.75 & 3.31 & 1.78 & $\mathrm{~V}_{6}$ & 22.97 & 1.61 & 2.68 & 1.6 \\
\hline $\operatorname{SEm} \pm$ & 0.103 & 0.007 & 0.007 & 0.072 & $\mathrm{SEm} \pm$ & 0.037 & 0.007 & 0.007 & 0.061 \\
\hline $\mathrm{CD}(p=0.05)$ & 0.286 & 0.019 & 0.019 & 0.200 & $\mathrm{CD}(p=0.05)$ & 0.104 & 0.019 & 0.019 & 0.170 \\
\hline \multicolumn{5}{|l|}{ Interaction } & \multicolumn{5}{|l|}{ Interaction } \\
\hline $\mathrm{SEm} \pm$ & 0.206 & 0.014 & 0.014 & 0.144 & $\mathrm{SEm} \pm$ & 0.075 & 0.014 & 0.014 & 0.123 \\
\hline $\mathrm{CD}(p=0.05)$ & 0.572 & N.S. & 0.038 & N.S. & $\mathrm{CD}(p=0.05)$ & 0.208 & 0.038 & 0.038 & 0.341 \\
\hline \multicolumn{5}{|c|}{ Moisture regimes at $60 \mathrm{DAS}$} & \multicolumn{5}{|c|}{ Moisture regimes at $120 \mathrm{DAS}$} \\
\hline $\mathrm{M}_{1}$ & 20.00 & 0.78 & 3.43 & 2.35 & $\mathrm{M}_{1}$ & 20.09 & 1.49 & 2.37 & 1.91 \\
\hline $\mathrm{M}_{2}$ & 21.52 & 0.77 & 3.52 & 2.44 & $\mathrm{M}_{2}$ & 21.40 & 1.47 & 2.45 & 2.23 \\
\hline $\mathrm{M}_{3}$ & 23.57 & 0.75 & 3.73 & 2.56 & $\mathrm{M}_{3}$ & 22.03 & 1.43 & 2.52 & 2.32 \\
\hline $\mathrm{M}_{4}$ & 24.04 & 0.69 & 3.81 & 2.61 & $\mathrm{M}_{4}$ & 23.23 & 1.43 & 2.63 & 2.45 \\
\hline $\mathrm{SEm} \pm$ & 0.049 & 0.005 & 0.006 & 0.050 & $\operatorname{SEm} \pm$ & 0.057 & 0.005 & 0.006 & 0.050 \\
\hline $\mathrm{CD}(p=0.05)$ & 0.138 & 0.015 & 0.016 & 0.139 & $\mathrm{CD}(p=0.05)$ & 0.160 & 0.015 & 0.016 & 0.139 \\
\hline \multicolumn{5}{|l|}{ Genotypes } & \multicolumn{5}{|l|}{ Genotypes } \\
\hline $\mathrm{V}_{1}$ & 22.94 & 0.59 & 3.34 & 2.9 & $\mathrm{~V}_{1}$ & 22.05 & 1.21 & 2.86 & 2.68 \\
\hline $\mathrm{V}_{2}$ & 23.99 & 0.46 & 4.04 & 3.04 & $\mathrm{~V}_{2}$ & 24.00 & 1.21 & 2.48 & 2.81 \\
\hline $\mathrm{V}_{3}$ & 23.31 & 0.94 & 3.44 & 2.6 & $\mathrm{~V}_{3}$ & 23.35 & 1.67 & 2.12 & 2.4 \\
\hline $\mathrm{V}_{4}$ & 22.30 & 0.62 & 3.92 & 2.82 & $\mathrm{~V}_{4}$ & 20.47 & 1.37 & 2.38 & 2.39 \\
\hline $\mathrm{SEm} \pm$ & 0.061 & 0.007 & 0.008 & 0.061 & $\mathrm{~V}_{5}$ & 19.06 & 1.46 & 2.51 & 1.59 \\
\hline $\mathrm{CD}(p=0.05)$ & 0.169 & 0.019 & 0.020 & 0.170 & $\mathrm{~V}_{6}$ & 21.19 & 1.81 & 2.59 & 1.51 \\
\hline \multicolumn{5}{|l|}{ Interaction } & $\mathrm{SEm} \pm$ & 0.070 & 0.007 & 0.007 & 0.061 \\
\hline $\mathrm{SEm} \pm$ & 0.122 & 0.014 & 0.014 & 0.123 & $\mathrm{CD}(p=0.05)$ & 0.196 & 0.019 & 0.019 & 0.170 \\
\hline $\mathrm{CD}(p=0.05)$ & 0.339 & 0.038 & 0.039 & N.S. & Interaction & & & & \\
\hline \multirow{2}{*}{\multicolumn{5}{|c|}{$\begin{array}{l}\text { PCL: Protein content of leaves; NRAL: Nitrate reductase } \\
\text { activity of leaves }\end{array}$}} & $\overline{\mathrm{SEm} \pm}$ & 0.141 & 0.014 & 0.014 & 0.123 \\
\hline & & & & & $\mathrm{CD}(p=0.05)$ & 0.393 & 0.038 & 0.039 & 0.341 \\
\hline
\end{tabular}


total sugar $\left(22.36 \mathrm{mg} \mathrm{g}^{-1} \mathrm{FW}\right)$, protein content $\left(4.32 \mu\right.$ mole g $^{-1}$ FW), NR activity $\left(2.67 \mu\right.$ moles of $\mathrm{NO}_{2}^{-}$formed $\mathrm{g}^{-1}$ f. wt. $\left.\mathrm{h}^{-1}\right)$ while moisture regime $\mathrm{M}_{1}$ showed significantly lowest total $\operatorname{sugar}\left(18.41 \mathrm{mg} \mathrm{g}^{-1} \mathrm{FW}\right)$, protein content $\left(3.41 \mu\right.$ mole g$\left.^{-1} \mathrm{FW}\right)$ and NR activity $\left(2.38 \mu\right.$ moles of $\mathrm{NO}_{2}^{-}$formed $\mathrm{g}^{-1} \mathrm{f}$. wt. $\left.\mathrm{h}^{-1}\right)$. Thereafter, similar trend was noticed at 60,90 and at harvest. However, the moisture regime $\mathrm{M}_{1}$ showed significantly highest proline content $\left(0.63 \mu\right.$ mole g $\left.^{-1} \mathrm{FW}\right)$ followed by $\mathrm{M}_{2}$ while $\mathrm{M}_{4}$ showed lowest proline content $\left(0.55 \mu\right.$ mole g $\left.^{-1} \mathrm{FW}\right)$. Similar trend for proline content was found at $60 \mathrm{DAS}, 90 \mathrm{DAS}$ and at harvest. The present study was aimed to understand the effect of moisture stress on biochemical and yield attributes in sorghum cultivars in terms of total sugar, proline, protein content and NR activity and yield parameters. A comparative analysis of different sorghum cultivars under water stress revealed that the higher proline content was noticed in genotype $\mathrm{V}_{6}$ (Phule Maulee) under lowest moisture stress condition $M_{1}(25 \%$ of F.C) as well as the genotype $\mathrm{V}_{2}$ (RSV-1006) recorded higher total sugar content, protein content and of nitrate reductase activity under higher moisture regime $\mathrm{M}_{4}$. The genotype $\mathrm{V}_{1}$ (Phule Yashoda) and $\mathrm{V}_{2}$ (RSV-1006) recorded higher grain and fodder yield at stress as well as non-stress situation than rest of genotypes.

In the present study it has been observed that the proline content increased with a decrease in the soil moisture content. These are in conformity with the findings of Mulla et al. (2006) and Satbhai et al. (1997). The genotypes $V_{6}$ (Phule Maulee), $V_{3}$ (Phule Chitra) and $\mathrm{V}_{5}$ (Phule Anuradha) recorded significantly highest proline content under moisture stress condition $\left(\mathrm{M}_{1}\right)$ than non moisture stress $\left(\mathrm{M}_{4}\right)$. The present study indicated that the proline content also had significant negative correlation with grain yield and positive correlation with NR activity at all critical growth stages. This clearly indicates that proline accumulation increased as the soil moisture content decreased. These results are in conformity with the findings of Bhaskaran et al. (1985), who stated that the proline accumulation increased in response to water stress. Similarly (Morgan et al., 1984) also reported positive correlation of proline accumulation with grain yield in water limited environment. Proline accumulation was seen in wheat genotypes due to the imposition of osmotic stress PEG6000 (Mujtaba et al., 2007). High levels of proline enable a plant to maintain low water potentials, allowing additional water to be taken up from the environment, thus buffering the immediate effect of water shortages within the organism (Kumar et al., 2003). This helps plants supply energy for growth and survival, thereby helping the plant to tolerate stress (Sankar et al., 2007).

The significantly lowest protein content in the genotype $\mathrm{V}_{6}$ (Phule Maulee), $\mathrm{V}_{3}$ (Phule Chitra) and $\mathrm{V}_{5}$ (Phule Anuradha) was recorded at moisture stress condition $\mathrm{M}_{1}$. However, protein content significantly reduced in genotype $\mathrm{V}_{6}$ (Phule Maulee) and $\mathrm{V}_{3}$ (Phule Chitra) under limited moisture stress condition $\mathrm{M}_{1}$. The degree of reduction in protein content as a function of water stress was less in $\mathrm{V}_{6}, \mathrm{~V}_{3}$ and $\mathrm{V}_{5}$ respectively. Protein content had decreasing trend with increase in water stress (Ranieri et al., 1989). In general, the content of protein in different sorghum cultivars progressively decreased with linear increase in water stress. The results obtained in the present investigation are supported by (Sharma et al., 1990) who reported similar trend in groundnut under water stress. Sarkar et al. (1989) reported that decrease in protein content in pea seedlings under PEG induced water stress. A decrease in protein content response to drought is an important criterion in understanding the growth and metabolism under water stress. The decline in protein content due to water stress may attributes to enhanced protein hydrolysis and impaired protein synthesis as well as reduction in total amino acid pool (Ranieri et al., 1989). Water stress increases the level of some amino acids like proline and glycine betaine due to protein breakdown, which probably provide some compatible osmoticum in the cytoplast there by maintaining low osmotic potential for retention of water within plant cell (Prakash et al., 1988). Decreased protein content under water stress could be attributed to reduced availability of amino acids (Davidson and Chanvalier, 1992). The total sugar content increased from 30 DAS to harvest in all the genotypes. The genotype $\mathrm{V}_{2}$ (RSV-1006) has maximum total soluble sugar content. The decrease in soil moisture content and RLWC increased total sugar content in leaves at 60, 90 DAS and harvest. It may be because of increased activity of the amylase. The genotype which had high content of total sugars at 60 and 90 days and at harvest also performed better with respect to yield and yield components and other growth characters which could probably due to the maintenance of leaf water status through osmoregulation This could be another reason for higher yield in these genotypes. These results supported findings which stated that as water stress increase proportionate decrease in total sugar occurs (Deshmukh et al., 2001).

The significant interaction was found between plant genotypes and moisture regimes at all critical growth stages with respect of total sugar content. At 30 DAS, genotype $\mathrm{V}_{2}$ (RSV-1006) with $\mathrm{M}_{4}$ recorded significantly highest total sugar (24.48 $\mathrm{mg}$ $\mathrm{g}^{-1} \mathrm{FW}$ ) while $\mathrm{V}_{5}$ (Phule Anuradha) with $\mathrm{M}_{1}\left(15.43 \mathrm{mg} \mathrm{g}^{-1} \mathrm{FW}\right)$ recorded lowest. On same interval $\mathrm{V}_{3}$ (Phule Chitra) with $\mathrm{M}_{4}$ showed significantly highest protein content $\left(4.93 \mu\right.$ mole g $^{-1}$ FW) and $\mathrm{V}_{6}$ (Phule Maulee) with $\mathrm{M}_{1}$ recorded lowest protein content $\left(3.20 \mu\right.$ mole $\left.\mathrm{g}^{-1} \mathrm{FW}\right)$. Similar trend was found at 60 , 90 DAS, and at harvest as that of 30 DAS. At 60 DAS the genotype $\mathrm{V}_{6}$ (Phule Maulee) showed significantly highest proline content $\left(1.37 \mu\right.$ mole $\left.^{-1} \mathrm{FW}\right)$ with lowest moisture 
regime $\mathrm{M}_{1}$. While significantly lowest proline content $(0.40$ $\mu$ mole $\mathrm{g}^{-1} \mathrm{FW}$ ) was noticed in genotype $\mathrm{V}_{2}$ (RSV-1006) under $\mathrm{M}_{4}$. Similar trend was found at $90 \mathrm{DAS}$, and at harvest as that of $60 \mathrm{DAS}$. The significant interaction between plant genotypes and moisture regimes were recorded at all growth stages with protein content. The significant interaction between plant genotypes and moisture regimes were found at 90 DAS and at harvest. But it was found statistically non significant at 30 and 60 DAS. At 90 DAS, the genotype $\mathrm{V}_{2}$ (RSV-1006) with moisture regime $\mathrm{M}_{4}$ showed significantly maximum NR activity $\left(3.05 \mu\right.$ moles of $\mathrm{NO}_{2}^{-}$formed $\mathrm{g}^{-1} \mathrm{f}$. wt. $\left.\mathrm{h}^{-1}\right)$ than rest of genotypes. While the significantly minimum NR activity (1.45 $\mu$ moles of $\mathrm{NO}_{2}^{-}$formed $\mathrm{g}^{-1} \mathrm{f}$. wt. $\mathrm{h}^{-1}$ ) was noticed in genotype $\mathrm{V}_{6}$ (Phule Maulee) under minimum moisture regime $\mathrm{M}_{1}$. Similar trend was observed at harvest at that of 90 DAS. The loss of nitrate reductase activity in response to water stress has been well established (Anikiev and Kuramagonedov, 1975). A most widely accepted explanation for the reduction in NR activity during water stress could be seen to be the inactivation of the enzyme, reduction in the availability of nitrate, inhibition of protein synthesis, consequent upon the reduction in the availability of NADH through the effect on photosynthesis, respiration and also changes in redox potential NR activity during water deficit is an important determinant of growth. In the present study the data on NR activity indicated that it decreased from 30 to 90 DAS in all the genotypes. The decrease in NR activity from 30 DAS onwards could be due to decrease in soil moisture content and RLWC. The genotypes $\mathrm{V}_{6}$ (Phlule Maulee), $\mathrm{V}_{3}$ (Phule Chitra) and $\mathrm{V}_{5}$ (Phule Anuradha) had the lowest NR activity under moisture regime $M_{1}$. However the genotype $\mathrm{V}_{2}$ (RSV-1006) and $\mathrm{V}_{1}$ (Phule Yashoda) had the higher NR activity. The present findings are in agreement with earlier reported reviews which showed a decline in water potential caused decline in NR activity in sorghum and pea (Chandra et al., 1983; Sivaramkrishnan et al., 1988). In the present study there was positive correlation of NR activity with total dry matter accumulation at all growth stages. These results were conformity with findings of Chandrashekhar (1980).

\subsection{Post harvest studies (at harvest)}

Earlier it has been reported that positive association of leaf area with grain yield could be considered as selection criterion under drought stress situations (Patil et al., 2003). The positive correlation between number of leaves and grain yield of sorghum was observed by Chaudhari and Mahajan (1978). Correlation study also indicated that LAI had significant positive association with grain yield (Lin and Yeh, 1990; Pawar and Jadhav, 1996).

The grain yield and yield attribute, viz., length and girth of ear head, dry weight of ear head, 1000 grain weight, grain yield plot $^{-1}$ and hectare, harvesting index and biological yield are pooled over rabi season. The relevant data are presented in Table 1 and 2. Except girth of ear head all other parameters were statistically significant over pooled data. The genotype $\mathrm{V}_{1}$ (Phule Yashoda) registered significantly highest length of ear head $(22.84 \mathrm{~cm})$, dry weight of ear head $(95.03 \mathrm{~g})$, fodder yield ha ${ }^{-1}\left(94.01 \mathrm{q} \mathrm{ha}^{-1}\right)$, grain yield plot ${ }^{-1}\left(2.78 \mathrm{~kg} \mathrm{plot}^{-1}\right)$, biological yield (130.62 $\mathrm{q} \mathrm{ha}^{-1}$ ). The genotype $\mathrm{V}_{5}$ (Phule Anuradha) recorded minimum girth of ear head $\left(5.66 \mathrm{~cm}^{2}\right)$, dry weight of ear head $(63.42 \mathrm{~g})$, panicle length $(18.27 \mathrm{~cm})$, 1000 grain weight $(35.39 \mathrm{~g})$, fodder yield ha- $\left(68.65 \mathrm{q} \mathrm{ha}^{-1}\right)$, grain yield plant ${ }^{-1}\left(1.77 \mathrm{~kg} \mathrm{plot}^{-1}\right)$, grain yield ha- ${ }^{-1}(23.32 \mathrm{q}$ $\left.\mathrm{ha}^{-1}\right)$, biological yield ha ${ }^{-1}\left(91.97 \mathrm{q} \mathrm{ha}^{-1}\right)$ and harvest index (25.42\%). The genotype $\mathrm{V}_{2}$ (RSV-1006) showed highest girth of ear head $\left(7.40 \mathrm{~cm}^{2}\right), 1000$ grain weight $(40.94 \mathrm{~g})$ and harvest index $(28.25 \%)$.

The significantly maximum length of ear head $(23.11 \mathrm{~cm})$ was recorded in moisture regime $M_{4}$ followed by $M_{3}$ while minimum length $(19.49 \mathrm{~cm})$ was found in $\mathrm{M}_{1}$. The moisture regime $\mathrm{M}_{4}$ recorded highest while $\mathrm{M}_{1}$ recorded lowest girth of ear head $\left(7.07 \mathrm{~cm}^{2}, 6.12 \mathrm{~cm}^{2}\right)$, dry weight of ear head $(89.53$ g, $72.53 \mathrm{~g}), 1000$ grain weight $(41.44,37.00)$, fodder yield ha $^{-1}\left(95.58 \mathrm{q} \mathrm{ha}^{-1}, 65.86 \mathrm{q} \mathrm{ha}^{-1}\right)$, grain yield plot ${ }^{-1}(2.81,1.90)$, grain yield he- $(37.14,24.98)$, biological yield (132.72 $\mathrm{q} \mathrm{ha}^{-1}$, $\left.90.96 \mathrm{q} \mathrm{ha}^{-1}\right)$ and harvest index $(27.92,27.38)$.

The significant interaction between plant genotypes and moisture regimes were found with respect to grain yield and yield attributes. The genotype $\mathrm{V}_{2}(\mathrm{RSV}-1006)$ with moisture regimes $M_{4}$ showed significantly highest length of panicle $(24.81 \mathrm{~cm}), 1000$ grain weight $(44.23 \mathrm{~g})$, fodder yield $\mathrm{ha}^{-1}\left(112.82 \mathrm{q} \mathrm{ha}^{-1}\right)$, grain yield plot ${ }^{-1}\left(3.40 \mathrm{~kg} \mathrm{plot}^{-1}\right)$, grain yield (44.92 $\left.\mathrm{ha}^{-1}\right)$ and biological yield (157.73 q ha-1). The genotype $\mathrm{V}_{5}$ (Phule Anuradha) with $\mathrm{M}_{1}$ recorded significantly lowest length of panicle $(16.10 \mathrm{~cm})$, dry weight of ear head $(54.23 \mathrm{~g}), 1000$ grain weight $(33.18 \mathrm{~g})$, fodder yield ha ${ }^{-1}(49.18$ q ha $\left.{ }^{-1}\right)$, grain yield plot ${ }^{-1}\left(1.39 \mathrm{~kg} \mathrm{plot}^{-1}\right)$, grain yield $\left(18.17 \mathrm{ha}^{-1}\right)$ and biological yield $\left(67.55 \mathrm{q} \mathrm{ha}^{-1}\right.$ ). The genotype $\mathrm{V}_{1}$ (Phule Yashoda) with moisture regime $\mathrm{M}_{4}$ registered significantly highest dry weight of ear head (101.98 g). The genotype $\mathrm{V}_{6}$ (Phule Maulee) with moisture regime $\mathrm{M}_{3}$ showed highest harvest index (29.62\%). The genotype $\mathrm{V}_{5}$ (Phule Anuradha) under moisture regime $\mathrm{M}_{3}$ noted significantly lowest harvest index (24.39). In present study the highest mean grain yield plant ${ }^{-1}$ obtained by the genotype $V_{1}$ (Phule Yashoda) and genotype $\mathrm{V}_{2}(\mathrm{RSV}-1006)$ under lowest regime $\mathrm{M}_{1}(25 \%$ of F.C) as well as non stress condition $\mathrm{M}_{4}(>90 \%$ of F.C) appeared due to its higher mean length and girth of ear head, dry weight of ear head, 1000 grain weight, dry matter accumulation at maturity which played important role to increase grain yield. The higher grain yield with higher values of all growth parameters are in 
conformity with Channappagouda et al. (2008). Seed yield is primarily limited by relatively short duration of soil moisture during the later phases of reproductive development (Sinaki et al., 2007). Moreover, these authors have indicated that at early stage of flowering water stress increased death of floret and loss of seed size which resulted in reduction of harvest index of seed plant ${ }^{-1}$ (Seghatoleslami et al., 2008).

Perhaps the decline in the thousand seed weight might be because of floret death resulting from water stress during post flowering (Prasad et al., 2008). Besides low grain yield panicle ${ }^{-1}$ in genotype $\mathrm{V}_{5}$ (Phule Anuradha) and $\mathrm{V}_{6}$ (Phule Maulee) was reflected in parallel decline in translocation of assimilation rate. This is due to the fact that spikelet fertility is related to assimilation rate during anthesis and its susceptibility to water stress in most crop plants (Praba et al., 2009).

The genotype $\mathrm{V}_{3}$ (Phule Chitra) and $\mathrm{V}_{4}$ (Phule Vasudha) had moderate length, girth and dry weight of ear head and 1000 grain weight but lower yield plant ${ }^{-1}$ because of lower ear head length and girth and dry weight of ear head. The number of research workers viz., (Narkhede et al.,1998; Shinde et al. 2003; Naik ,1990; Ravikumar et al. 2003; Nirmal et al., 2008; Patil et al., 2008; Channapagoudar et al., 2008; Reddy et al., 2012) obtained significant positive correlation of various yield contributing characters with mean grain yield plant ${ }^{-1}$. These existed positive and significant association of total chlorophyll content in leaf, at $50 \%$ flowering and drought stages with grain and fodder yield. These results were coincided with (Surywanshi et al., 2010). Those high yielding genotypes possess higher morphological parameters such plant height, number of leaves plant ${ }^{-1}, \mathrm{LA}, \mathrm{LAI}$ and LAD and accumulation of more biomass productivity, harvest index, $5-10 \%$ ear head emergence, $5 \%$ bolder seed. These traits lead to development of new varieties suitable for medium soil situations. Apart from high panicle dry matter ( $50 \%$ of total dry matter), these varieties should also have efficiency in conversion of photosynthesis to the grain, these findings was supported by (Reddy et al., 2012). Grain yield is positively correlated with function of the dry matter production, it's partitioning and harvest index generally leads to higher yield. It could be seen that the higher yield resulted from the higher mean biomass production $\left(\mathrm{g}\right.$ plant $\left.{ }^{-1}\right)$ coupled with higher harvest index. The genotypes $\mathrm{V}_{1}$ (Phule Yadhoda) and $V_{2}$ (RSV-1006) obtained comparatively higher grain yield than others. In present investigation, harvest index showed significant positive correlation with grain yield plant ${ }^{-1}$. (Narkhede et al., 1998) also reported similar result.

\section{Conclusion}

Genotype Phule Chitra and Phule Maulee are more suited under limited soil moisture condition. While genotype RSV-
1006 found well suited for medium soil for stress as well as non-stress condition. Irrespective of moisture regimes, Phule Yashoda and RSV-1006 found better than rest of genotypes based on physiological, biochemical and yield parameters. However, Phule Chitra and Phule Maulee had some biochemical and physiological parameters which suited under low moisture regimes $\left(\mathrm{M}_{1}\right)$ i.e., under water stress condition.

\section{Acknowledgement}

The author expresses their deep sense of gratitude to Dr. U.D., Chavan, Associate Professor and Senior Cereal Food Technologist, Department of Agril. Botany, Mahatma Phule Krishi Vidyapeeth, Rahuri, District Ahmednagar, Maharashtra, India, for providing lab facilities and timely guidance.

\section{Conflict of Interests}

The author declares there is no conflict of interests regarding the publications of this paper.

\section{References}

Abdalla, M.M., El-Khoshiban, N.H., 2007. The influence of water stress on growth, relative water content, photosynthetic pigments, some metabolic and hormonal contents of Triticum aestivum cultivars. Journal of Applied Science Research 3, 2062-2074.

Anikiev, V.V., Kuramagomedov, M.K., 1975. Activity of nitrate reductase in leaves of barley shoots at different levels of soil moisture. Plant Physiology 22, 293-297.

Barnett, N.M., Naylor, A.W., 1966. Amino acid and protein metabolism in Barmuda grass during water stress. Plant Physiology 41, 1222-1230.

Bates, L.S., Waldren, R.P., Teare, I.D., 1973. Rapid determination of free proline for water stress study. Plant Physiology 39, 205-207.

Bayoumi, T.Y., Eid, M.H., Metwali, E.M., 2008. Application of physiological and biochemical indices as a screening technique for drought tolerance in wheat genotypes. African. Journal Biotechnology 7, 2341-2352.

Belum, V.S., Reddy, A., Ashok Kumar., Reddy, S.P., 2010. Recent Advances in Sorghum Improvement Research at ICRISAT. Kasetsart Journal. (Nature Science) 44, 499-506.

Bhaskaran, S., Smith, R.H., Newton, R.J., 1985. Physiological changes in cultured sorghum cells in response to induced water stress. Plant Physiology 79(1), 266-269.

Blum, A., Ebercon, A., 1976. Genotypic responses in sorghum to drought stress. III. Free proline accumulation and drought resistance. Crop Science 16, 428-431.

Chand, P., Singh, P.K., 2003. Evaluation of sorghum (Sorghum bicolor L.) genotypes for drought tolerance. 
Indian Journal of Dryland Agricultural Research and Development 18(1), 92-94.

Chandra, R., Sirohi, G.S., Raghuveer, P., 1983. Effect of moisture stress on nitrate reductase activity (NRA) in pea (Pisum sativum $\mathrm{L}$.) $\left(\mathrm{C}_{3}\right)$ and sorghum (Sorghum vulgare Pers) $\left[\mathrm{C}_{4}\right]$ Plants. Journal of Plant Nutrition 6, 629-640.

Chandrashekhar., 1980. Nitrate reductase activity and dry matter accumulation in sorghum. M.Sc., (Agri) Thesis, University of Agricultural Sciences, Bangalore.

Channappagoudar, B.B., Biradar, T.D., Bhara, M., Rokhade, C.J., 2008. Morpho-physiological traits of sorghum parental lines determining grain yield and biomass. Karnataka Journal Agricultural Science 21(2), 168-170.

Chaudhari, S.D., Mahajan, S.N., 1978. Effect of genotype differences in leaf area, height and flowering on yield and yield components of sorghum. Journal Maharashtra agriculture University 3(1), 71-73.

Davidson, D.S., Chanvalier, M., 1992. Storage and remobilization of water soluble carbohydrates in stress of spring wheat. Crop Science 32, 435-447.

Deshmukh, D.V., Mhase, L.B., Jamadagni, B.M., 2001. Evaluation of chickpea genotypes for drought tolerance. Indian Journal of Pulses Research 17, 47-49.

Dubois, M., Gilles, K.A., Hamilton, J.K., Rebers, P.A., Smith, F., 1956. Colorimetric method for determination of sugars and related substances. Annals of Chemistry 28, 350-356.

Flores, H.E., Galston, A.W., 1984. Osmotic stress induced polyamind accumulation in cereals, leaves. II $^{\text {nd }}$ relation to amino acid tools. Plant Physiology 75(1), 110-113.

Gaosgelwe, P.L., Kirshan, M.B., 1990. Evaluation of wild primitize and adopted Sorghum for drought resistance. In challenges of dry land agriculture a global perspective. Proceeding for the international conference on dry land farming. Bushland, USA, 15-19, Texas, USA, 224-226.

Hageman, R.H., Hucklesby, D.P., 1971. Nitrate reeducates activity from higher plants. Methods of Enzymology 23, 491-503.

Hiremath, S.M., Parvatikar, S.R., 1985. Growth and yield analysis in sorghum-identification of genotypes with low leaf area and high dry matter production. Sorghum News letter 28, 108-109.

Khannan, C.R., Rao, P.S.S., Maheswar, M., Aobing, L., Sbaivchankar, K. S., 1994. Effect of water deficit on accumulation of dry matter carbon and nitrogen in the kernel of wheat genotypes differing in yield stability. Annals of Botany 74, 503-511.

Kulkarni, L.P., Narayana, R., Krihnasastry, K.S., 1981. Photosynthetic efficacy of transpiration in relation to leaf characters and productivity in sorghum genotypes. Sorghum News letter 24, 124-125.
Kumar, R.N., Mohammad, S., Lawarence, M., 2009. Influence of time and method of sowing of parental lines and nitrogen dose on the phenology of flowering, seed set and yield of CSH-14 sorghum hybrid. Indian Journal of Agricultural Science 70(11), 781-783.

Kumar, S.G., Mattareddy, A., Sudhakar, C., 2003. NaCL effects on proline metabolism in two high yielding genotypes of mulberry (Morus alba L.) contrasting salt tolerance. Plant Science 165, 1245-1251.

Lowery, O.H., Rosebrough, N.J., Farr, A.L., Randall, R.J., 1951. Protein measurement with folinphenol reagent. Journal of biological Chemistary 193, 265-275.

Maiti, R.K., Limon, S.M., Ebeling, P.W., 2000. Responses of some crops to various abiotic stress factors and its physiological and biochemical basis of resistance. Agriculture Review 21, 155-167.

Mali, P.C., Mehta, S.L., 1977. Effect of drought on enzymes and free proline in rice varieties. Phytochemistry 16, 1355-1357.

Morgan, J.M., 1984. Osmoregulation and water stress in higher plants. Annual Review of Plant Physiology 35, 299--319.

Mujtaba, M., Ali, M., Ashraf, M.Y., Khanzada, B., Farhan, S.M., Shirazi, M.U., Khan, M.A., Shereen, A., Mumtaz, S., 2007. Physiological responses of wheat genotypes under water stress conditions at seedling stage. Pakistan Journal of Botany 39(7), 2575-2579.

Mulla, M.S., Munjal, S.V., Salhbhai, R.D., Naik, R.M., 2006. Metabolic alternations associated with water stressed at critical growth stages in rabi sorghum. Indian Journal of Agricultural Biochemistry 19(1), 5-9.

Munjal, N., Sawhey, S.K., Sawhney, V., Munjal, N., Sawhney, V, 1998. Ferricyanide restores nitrate reductase activity in leaf extracts of water stressed wheat seedlings. Plant Physiology 157, 577-579.

Naik, L.B., 1990. Studies on the variation of yield in sorghum genotypes. Madras Agriculture Journal 77, 370-378.

Narkhede, B.N., Shinde, M.S., Patil, S.P., 1998. Association of physiological parameters with grain yield of rabi sorghum. Annals of Plant Physiology 12(1), 65-66.

Narkhede, B.N., Shinde, M.S., Patil, S.P., 1998. Association of physiological parameters with grain yield of rabi sorghum. Annals of Plant Physiology 12(1), 65-66.

Nirmal, S.V., Patil, J.V., 2008. A new drought tolerant genotype of rabi sorghum SPV-1546 (Phule Chitra). Annals of Plant Physiology 22(2), 165-168.

Panse, V.G., Sukhatme, P.V., 1967. Statistical methods for agricultural workers. ICAR New Delhi., $2^{\text {nd }}$ Edn, 381.

Patil, J.V., Shinde, M.S., Chaudhary, S.B., 2008. Phule Chitra (SPV-1546) : A drought tolerant Rabi sorghum varieties for medium soils of Maharashtra. Annals of Plant 
Physiology 22(1), 64-68.

Patil, V.B., 2003. Droudht tolerance in sorghum by pollen selection using osmotic stress. Euphytica 133, 371-376.

Pawar, K.P., Jadhav, A.S., 1996. Correlation and path coefficient analysis in rabi sorghum. Journal of Maharashtra Agriculture University 21(3), 344-347.

Praba, M.J., Cairns, E., Babu, R.C., Lafitte, H.R., 2009. Identification of physiological traits underlying cultivar differences in drought tolerance in rice and wheat. Journal of Agronomy and Crop Science 195, 30-46.

Prakash, L., Dutt, M., Prathapasenan, G., 1988. $\mathrm{NaCl}$ alters content of nuclic acids, protein polyaminase and the activity of agmatine, diciminase during germination and seedling growth of rice (Oryza sativa L.). Journal of Plant Physiology 5(6), 769-776.

Prasad, P.V., Pisipati, S.R., Mutava, R.N., Tuinstra, M.R., 2008. Sensitivity of grain sorghum to high temperature stress during reproductive development. Crop Science 48, 1911-1917.

Ranieri, A., Bernardi, R., Lanese, R., Soladatini, G.R., 1989. Changes in free amino acid contet and protein pattern of maize seedling under water stress. Environmental and Experimental Botany 29, 351-357.

Rao, D.G., Sinha, S.K., 1990. Influence of leaf area on maintenance of water potential in sorghum hybrid (CSH6) and its parents under limited soil moisture condition. Indian Journal of Agriculture Science 60(8), 533-35.

Ravikumar, R.L., Patil, B.S., Salimath, P.M., 2003. Drought tolerance in sorghum by pollen selection using osmotic stress. Euphytica 133, 371-376.

Reddy, S., Patil, J.V., Nirmal, S.V., Gadakh, S.R., 2012. Improving post-rainy season sorghum productivity in medium soils: does ideotype breeding hold clue? Current Science 102(6), 121-126.

Sankar, B., Jaleel, C.A., Kishorekumar, A., Somasundaram, R., Panneeerselvam, R., 2007. Drought induced biochemical modificationsand proline metabolism in (Abelmoschus esculentus L.) Moench. Acta Botanica Croatica 66(1), 43-56.

Sarkar, R.K., Saini, J.P., Dhube, S.D., 1989. Studies on moisture stress and associated biochemical changes in pea seedling. Progressive Horticulture 21(1-2), 9-14.

Satbhai, R.D., Naik, R.M., Kale, A.A., Desai, B.B., 1997. Effect of water stress on metabolic alternations in rabi sorghum. Journal of Maharashtra agricultural University 22, 158-160.

Seghatoleslami, M., Kafi, M., Majid, E., 2008. Effect of drought stress at different growth stages on yield and water use efficiency of five Proso millet (Pannicum millaceum L.) genotypes. Pakistan Journal of Botany 40, 1427-1432.

Shinde, M.S., 2003. Physiological parameters in relation to grain yield in rabi sorghum on medium soil. Advances of Plant Science 16(1), 119-122.

Sharma, K., Singh, G., Sharma, R., Sharma, H.L., 1990. Biochemical changes in groundnut seed during germination under water stress condition. Annals of Biology 5, 123-127.

Sinaki, J. M., Haravan, E.M., Rad, A.H.S., Noormohammadi, G., Zarei, G., 2007. The effects of water deficit during growth stages of (canola Brassica napus L.) AmericanEurasian Journal of Agriculture and Environmental Science 2, 417-422.

Sivaramakrishnan, S., Patella, V.Z., Flower, D.J., Peacock, J.M., 1988. Proline accumulation and nitrate reductase activity in constructing sorghum lines during mid season drought stress. Physiologa Plantarum 74(3), 418-426.

Sonawane, V., Bhardu, R.W., Rnarase, S.A., Bhoge, R., Mate, N.S., 2008. Physiological characterization of rabi sorghum genotypes under different soil. Annals of Plant Physiology 22(2), 161-164.

Surywanshi, A., Chimmad, V.P., Ravikumar, R.L., 2010. Physiological studies on hybrids and parents in relation to leaf associated parameters in sorghum. Karnataka Journal of Agriculture Science 20(1), 21-24.

Watson, D.J., 1947. The dependence of net assimilation of the leaf area index. Annual of Botany 22, 37-35.

Zala, H.N., Bosamia, T.C., Kulkarni, K.S., Shukla, Y.M., 2014. Physiological and biochemical characterization for drought stress at seedling stage in wheat genotypes. International Journal of Bioresource and Stress Management 5(3), 386-394.

Zhang, M., Duan, L., Zhai, Z., Tian, X., Wang, B., He, Z., Li, Z., 2004. Effects of plant growth regulators on water deficit-induced yield loss in soybean. Proceedings of the 4th International Crop Science Congress, Brisbane, Australia. 